DOI https://doi.org/10.30525/978-9934-26-073-5-2-60

\title{
МЕТОДОЛОГИЧЕСКИЕ ПРИНЦИПЫ ФОРМИРОВАНИЯ ЛИНГВОКУЛЬТУРНОЙ КОМПЕТЕНЦИИ ИНОСТРАННЫХ УЧАЩИХСЯ
}

\author{
Тарлева А. В. \\ кандидат филологических наук, \\ доцент кафедры русского языка
}

Харьковского национального университета имени В. Н. Каразина, доцент кафедры языковой подготовки иностранных граждан Харьковского наиионального медииинского университета 2. Харьков, Украина

Проблема преподавания языка в иностранной аудитории предполагает решение нескольких задач: обучение фонетике, правописанию, грамматике, лексике, формирование всех видов речевой деятельности: чтения, письма, говорения, умения воспринимать звучащую речь.

Методисты подсчитали, что общее количество умений, которыми должен овладеть иностранный студент, приблизительно равно шестидесяти. Их определили путем перемножения всех перечисленных выше навыков, формируемых в процессе обучения, и уровней развития языковой личности (умение обобщать, насыщать сообщение информацией, адекватно подбирать социально правильный вариант высказывания и т.д.) [1].

Формирование языковой личности взрослого человека, для которого изучаемый язык не является ни родным, ни близкородственным, ни знакомым, помимо указанных особенностей, требует понимания лингвокультурных характеристик, норм и правил поведения, умения пользоваться понятными для носителей знаками, в противном случае его ожидает коммуникативный провал.

Как правило, студенты изучают язык, в первую очередь, именно с прагматическими целями, т. е. понимание всех тонкостей вербального и невербального поведения окружающих позволяет им почувствовать себя достаточно уверенно и независимо.

Процесс обучения неизбежно включают этап дифференциации и сопоставления получаемых знаний.

На уровне фонетики, когда преподаватель знакомит студентов с особенностями произношения звуков (и параллельно с правилами 
графического написания букв) студенты вычленяют те из них, которые похожи на родные и принимают как более понятные.

Так же происходит с остальными уровнями знакомства с языком. Слова, которые похожи на родные, грамматические правила, сопоставимые с правилами грамматики родного языка, воспринимаются легче и быстрее, если только не вступают в силу мешающие пониманию законы интерференции.

Формирование языковой компетентности представляется задачей номер один, однако без параллельной работы над развитием компетентностей речевых, комуникативных, социальных и других невозможна адекватная коммуникация.

Новая языковая личность формируется при взаимодействии сознания, языка и действительности.

И если ребенок усваивает язык, взаимодействуя с окружающим миром, то человек, изучающий иностранный язык, наоборот, изучает мир посредством языка.

Таким образом, задачей обучения, в первую очередь, становится формирование компетенций, позволяющих студенту воспринимать картину мира так, как ее воспринимает носитель языка.

Роль лингвокультурных знаний в этом случае невозможно переоценить.

Методология компонентного, лингвокультурологического, концептуального анализа единиц изучаемого и родного языков, примененная на практике, позволяет значительно расширить знания студента о новом языке, поскольку в процессе как синхронного, так и диахронического анализа функционирования понятия в поле зрения исследователя попадают слова и термины, связанные с рассматриваемым словом.

Чаще всего учащихся интересуют основополагающие понятия, формирующие базу картины мира, такие, как жизнь, смерть, человек, дом, добро, время, мать, отец, родина и т. д.

Различие в понятийном объеме рассматриваемого слова в различных языках формирует первичную картину фрагмента мира, в котором данное понятие существует.

Часто понятия, которые представляют собой концептуально важные элементы любой национальной картины мира и, на первый взгляд, отражают универсальные общечеловеческие представления о мире, могут удивлять необычными интерпретациями, такими составляющими значения, которые насколько прижились в культуре народа, что не вызывают сомнения и вопросов, при этом, с точки зрения другой культуры, кажутся удивительными и непредсказуемыми. Именно такие 
находки и представляют наибольшую интеллектуальную ценность для иностранцев.

Семантические поля, которые формируются вокруг слова, описывают не только ближайшие понятия, но целый фрагмент действительности.

Устное народное творчество передает сформированное на протяжении длительного времени представление о функции, качестве, особенностях понятия, его аксиологических характеристиках, которые вписываются в рамки важнейших в представлении фундаментальных для народа понятий системы: хорошо-плохо, правильно-неправильно, доброзло, а также варианты этих же характеристик в подсистемах: свое-чужое, верх-низ, далеко-близко и т. д.

Знакомство с этимологией слова уже формирует семантику слова, позволяет понять направления, в которых это значение будет развиваться.

Сравним этимологию слова Правда, например, в русском и английском языках.

Ю.С. Степанов пишет, что в русском языке оно «произведено от прилагательного правый, прямой и правильный, а также «честный, праведный, поступающий по совести», восходит к и.-е. корню *рго «вперед».

Слово правый значит образияовый, тот кто служит нормой $и$ примером для следования. Рус. слова zъlъ (злой) и осетинское zul «кривой» этимологически тождественны. [2, с. 461-462]

Таким образом, можно сказать, что «неправда, кривда» в предыстории оказывается родственной «злу», а «правда» - «добру» и «радости».

*pravьda образовано от прилагательного *pravъ.. *pravьda <*prav-iti, связанными со значениями: «правда», «поголовье скота», «правда, тяжба», «положение, закон, судебное дело» (словен. prâvda) [3, c. 352].

Английское слово true происходит ... от протогерманского * trewwj«иметь добросовестность», ... возможно, в конечном итоге от PIE * dru«дерево». Древнескандинавский trú, «вера, честное слово; религиозная вера, вера» (архаический английский troth «верность, честность, добросовестность», сравните Ásatrú).

Таким образом, «истина» включает в себя как «верность, лояльность, искренность, правдивость», так и «согласие с фактом или реальностью» в англосаксонском языке, выражаемое sōp (современный английский: истина).

Во всех германских языках, кроме английского, введено терминологическое различие между «верностью» истины и «фактичностью» 
истины. В некоторых современных контекстах слово «истина» используется для обозначения верности оригиналу или стандарту [4].

Таким образом, этимологически русское слово «правда» связано с понятиями прямой, первый, образцовый, в то время как английское truth связано как с религиозной верой и честностью, так и с согласием с фактом действия или события.

Понимание объема значения понятия позволяет говорить об особенностях его восприятия и употребления в разных языках.

Лингвокультурное содержание, заключенное в семантике концептов, проявляется в народном творчестве, фразеологизмах, паремиологических оборотах, афоризмах, прецедентных текстах, а также разговорном, публицистическом, научном, авторских художественных контекстах.

К примеру, при сравнении пословиц и поговорок о правде в русском и вьетнамском языках объем и содержание концептов качественно и количественно отличаются друг от друга. Несомненно, понятие правды в обеих культурах имеет много сходных черт: оно имеет высокие ценностные характеристики, играет роль в утверждении идеалов честности в борьбе со злом как источником разрушения, при этом требует от человека особых усилий, чтобы принять, распространять и защищать правду, поскольку правда не всем нравится.

Однако во вьетнамской культуре правда связана с некоторыми однозначными действиями в поведении людей, сравнивается с предметами. Утверждается, что правда всегда приносит вознаграждение.

В русской культуре правда, в первую очередь, зависит от божественного провидения. В картине мира русскоговорящих не всегда честному человеку легче жить. Кроме того, в русской культуре правда может быть связана с хитростью.

Внимание к тонкостям употребления слов в культуре изучаемого языка, знакомство с различными контекстами, в которых раскрывается полное значение концептов в языке-носителе, позволяет иностранным учащимся изучать язык на высоком уровне и формировать черты вторичной языковой личности.

\section{Литература: \\ 1. Самосенкова Т.В. Коммуникативное пространство препо-} давательского поля обучения РКИ: полилингвокультурный феномен URL: (http://cyberleninka.ru/article/n/kommunikativnoe-prostranstvo-prepodavatelskogo-polya-obucheniya-rki-polilingvokulturnyy-fenomen\#ixzz3mAsF MBu9) (дата обращения: 28.03.2021). 
2. Степанов Ю.С. Константы: Словарь русской культуры, изд. 3-е, испр. и доп.. М., Академический проект, 2004, 992 с.

3. Фасмер Макс Этимологический словарь русского языка. В 4 т. Т.3 (Муз-Сят). Пер. с нем. и доп. О.Н.Трубачева, 2-е изд, стер., М., Прогресс, 1987, $832 \mathrm{c}$.

4. Truth. https://en.wikipedia.org/wiki/Truth\#: :text=Definition\%20and $\% 20$ etymology,Further\%20information $\% 3 \mathrm{~A} \% 20$ Veritas\&text=The $\% 20$ Englis $\mathrm{h} \% 20$ word $\% 20$ truth $\% 20$ is, German $\% 20$ triuwida $\% 2 \mathrm{C} \% 20 \mathrm{Old} \% 20$ Norse $\% 20 \mathrm{tr}$ ygg\%C3\%B0.\&text=Old $\% 20$ Norse $\% 20$ tr $\% \mathrm{C} 3 \% \mathrm{BA} \% 2 \mathrm{C} \% 20 \% 22$ faith $\% 2 \mathrm{C}$,f aith\%22\%2C\%20compare\%20\%C3\%81satr\%C3\%BA)) (дата обращения: 3.04.2021).

DOI https://doi.org/10.30525/978-9934-26-073-5-2-61

\title{
ЩОДО МОДЕЛЮВАННЯ ЛЕКСИЧНОГО ЗНАЧЕННЯ ДИХОТОМІЇ «СВІЙ / ЧУЖИЙ» З УРАХУВАННЯМ НАЯВНОСТІ ФРАЗЕОЛОГІЗМУ
}

\author{
Шепель Ю. О. \\ доктор філологічних наук, професор, \\ професор кафедри перекладу \\ та лінгвістичної підготовки іноземчів, \\ академік Національної академії наук вищої освіти України, \\ Дніпровського начіонального університету імені Олеся Гончара
}

\section{Панченко О. I.}

доктор філологічних наук, професор, професор кафедри перекладу та лінгвістичної підготовки іноземців, Дніпровського начіонального університету імені Олеся Гончара м. Дніпро, Україна

Під час аналізу значення фразеологізмів важливим $є$ виокремлення сем, семантичних елементів менших, ніж той або той аспект фразеологічного значення.

Чеський лінгвіст В. Скаличка запропонував термін «сема» для позначення мікроелемента плану змісту. Семи - свого роду «атоми» значення, що входять до складу макроелементів - аспектів значення. Семи можна схарактеризувати як мікроелементи значення, що позначають реальні або уявні ознаки денотатів. В. Г. Гак визначає три типи 